\title{
Comparative Study of Islamic Religious Education (PAI) Leraning Management at Elementary School
}

\author{
Lisawati \\ Program Pascasarjana Universitas Muhammadiyah Sumatera Barat \\ lisawati84@gmail.com
}

\begin{abstract}
Islamic religious education learning at each educational institution has a different management pattern even though at one level within the education unit level, differences in management need to be disclosed as an effort to obtain information related to the strengths and weaknesses of each institution, related to this, this study aimed to find out the management of Islamic religious education carried out by teachers at two public elementary schools. From the data analysis conducted, Islamic religious education management at SD Negeri 02 and 13 Petok Pasaman are: 1) Islamic teachers carry out various preparations and designs before implementing learning, the preparation of learning plans was carried out through studies of various aspects related to learning. 2) the learning implementation by the teachers of SDN 02 was quite creative and innovative, in contrast to the Islamic religious education at SD Negeri 13 which still relies on conventional aspects of learning methods and media. 3)Islamic teacher of SD Negeri 02 Petok conducted a conceptual, structured, and systematic learning evaluation.
\end{abstract}

Keywords: plan, implementation, evaluation, Islamic religious education

\begin{abstract}
Abstrak
Pembelajaran Pendidikan Agama Islam pada setiap lembaga pendidikan memiliki pola management yang berbeda walaupun dalam satu level dalam tingkat satuan pendidikan, perbedaan managemen perlu untuk diungkapkan sebagai upaya mendapatkan informasi yang terkait dengan kelebihan dan kelemahan pada masing-masing lembaga, terkait dengan itu penelitian ini bertujuan untuk mengetahui management pembelajaran PAI yang dilakukan guru pada dua sekolah Dasar Negeri. Dari analisis data yang dilakukan diketahui bahwa manajemen pembelajaran PAI di SD Negeri 02 dan 13 Petok Pasaman ialah: 1) guru PAI melakukakan berbagai persiapan dan rancangan sebelum melaksanakan PBM, penyusunan RPP di sana dilakukan melalui kajian terhadap berbagai aspek yang terkait dengan pembelajaran. 2) Pelaksanaan pembelajaran guru SDN 02 cukup kreatif dan inovatif, berbeda dengan pembelajaran PAI yang ada di SD Negeri 13 yang masih mengandalkan konvensional dalam aspek metode dan media pembelajaran. 3) Guru PAI SD Negeri 02 Petok melakukan evaluasi pembelajaran secara terkonsep, terstruktur dan sistimatis.
\end{abstract}


Kata Kunci: perencanaan, pelaksanaan, evaluasi, pembelajaran PAI

\section{Pendahuluan}

Pembelajaran Pendidikan Agama Islam pada setiap lembaga pendidikan memiliki pola management yang berbeda walaupun dalam satu level dalam tingkat satuan pendidikan, perbedaan managemen perlu untuk diungkapkan sebagai upaya mendapatkan informasi yang terkait dengan kelebihan dan kelemahan pada masing-masing lembaga, terkait dengan itu penelitian ini bertujuan untuk mengetahui management pembelajaran PAI yang dilakukan guru pada dua sekolah Dasar Negeri. Dari analisis data yang dilakukan diketahui bahwa manajemen pembelajaran PAI di SD Negeri 02 dan 13 Petok Pasaman ialah: 1) guru PAI melakukakan berbagai persiapan dan rancangan sebelum melaksanakan PBM, penyusunan RPP di sana dilakukan melalui kajian terhadap berbagai aspek yang terkait dengan pembelajaran. 2) Pelaksanaan pembelajaran guru SDN 02 cukup kreatif dan inovatif, berbeda dengan pembelajaran PAI yang ada di SD Negeri 13 yang masih mengandalkan konvensional dalam aspek metode dan media pembelajaran. 3) Guru PAI SD Negeri 02 Petok melakukan evaluasi pembelajaran secara terkonsep, terstruktur dan sistimatis.

Kata Kunci: perencanaan, pelaksanaan, evaluasi, pembelajaran PAI

\section{Introduction}

\section{Hasil dan Pembahasan}

One of the indicators of quality learning is learning management, therefore, differences in management systems applied to educational institutions will show results and learning quality. This is in line with a statement by Maharani that every activity must begin with a good and mature plan ${ }^{1}$, as well as Hammod who stated that knowledge on education science will have implications for learning development ${ }^{2}$, besides that the learning evaluation system also determines the equivalence of learning outcomes ${ }^{3}$.

Planning, implementation, and evaluation as part of the learning management system have implications for learning quality so that the learning

1 Deviana Ika Maharani, M. Huda A.Y, and Imron Arifin, "Manajemen Pembelajaran Pondok Pesantren,” JMSP Journal Manajemen Dan Supervisi Pendidikan 1, no. 1 (2016): 17-23.

2 Linda Darling-hammond et al., "Implications for Educational Practice of the Science of Learning and Development," Applied Developmental Science 24, no. 2 (2020): 97-140, https://doi.org/10.1080/10888691.2018.1537791.

${ }^{3}$ Laura A Outhwaite, Anthea Gulliford, and Nicola J Pitchford, “A New Methodological Approach for Evaluating the Impact of Educational Intervention Implementation on Learning Outcomes," International Journal of Research \& Method in Education 43, no. 3 (2020): 225-42, https://doi.org/10.1080/1743727X.2019.1657081. 
management that applies to each education institution becomes the benchmark in determining learning quality.

Qasim and Maskiah stated that the learning plan is an activity that starts from recognizing the environment well, especially those related to students and learning materials, to developing a syllabus in the form of a learning plan preparation ${ }^{4}{ }^{5}$. The learning implementation is related to the activities that take place in delivering material using certain learning materials, media, and methods ${ }^{6}$. While learning evaluation is an activity carried out to determine and measure the achievement of predetermined goals ${ }^{7}$.

In line with the expert's view above, learning management which includes planning, implementation, and evaluation should run in parallel in realizing good learning quality. However, in fact, in some educational institutions, learning management has not actualized properly, as in the results of observations at SD Negeri 02 and 13 Petok Pasaman which showed that Islamic teachers have not implemented learning management optimally. The result of the observation is in line with the results of the interview with the principal of SD Negeri 02 Petok who stated that "in implementing learning, Islamic teachers do not fully understand the preparation of the learning plan, especially now using The 2013 Curriculum, because most of the teachers are old, so it is difficult to follow every development and change related to learning".

This is also in line with a statement by the Principal of SD Negeri 13 Petok who stated that "It seems that Islamic learning that is followed by students is less exciting, maybe because teachers have not been able to manage learning according to the development of students who are familiar with the technology. In current students, if learning is presented in a conventional style, they are less motivated in participating in learning, it seems that teachers need advanced professional development, related to learning systems and strategies.

In accordance with the results of observations and interviews as described above, the researcher had an interest in conducting a deeper study of Islamic religious education learning management carried out by teachers at the two institutions, therefore the purpose of this study was to compare: 1) learning plan by Islamic teachers at SD Negeri 02 and 13 Petok Pasaman, 2) Islamic religious

4 Muhammad Qasim and Maskiah, "Perencanaan Pengajaran Dalam Kegiatan Pembelajaran,” Jurnal Diskursus Islam 04, no. 03 (2016): 484-92.

${ }^{5}$ Mahyudin Ritonga, "Desain Bahan Ajar Bahasa Arab Sains Dengan Pendekatan Whole Language," EDUKASI: Jurnal Pendidikan Islam 5, no. 2 (2017): 001-024, https://doi.org/https://doi.org/10.5281/edukasi.v5i2.287.

6 Paul Hager, Alison Lee, and Ann Reich, Practice, Learning and Change: Practice-Theory Perspectives on Prodessional Learning (New York: Springer Dordrecht Heidelberg, 2012).

7 Azmahani A.Aziz, Khairiyah M. Yusof, and Jamaludin M. Yatim, "Evaluation on the Effectiveness of Learning Outcomes from Students' Perspectives," Procedia-Social and Behavioral Science 56 (2012): 22-30. 
education learning plan at SD Negeri 02 and 13 Petok Pasaman, and 3) Islamic religious education learning evaluation at SD Negeri 02 and 13 Petok Pasaman.

The results of the study will be useful for every Islamic teacher in Indonesia and observers of education and management of educational institutions, because even though the study was only conducted at two elementary schools in Pasaman, it is possible that there are similar problems with learning management, especially in Islamic religious education at other educational institutions in Indonesia.

\section{Literature Review}

Learning management is based on a general definition of management, which is an activity carried out in a structured manner starting from planning, implementation, and evaluation. In this case, not all management components were used by the researchers as stated by Safiein that management has four main components, namely plan, organizing, implementation, and evaluation systems ${ }^{8}$. However, in this study researchers used theories related to plan, implementation, and evaluation, the theory was used because in learning, organizing is in line with learning implementation.

The learning plan is a must, by making a good plan, it is hoped that it can help teachers to realize good learning quality. To make a good plan, a teacher must conduct a study of needs ${ }^{9}$, student characteristics, school environment, the readiness of supporting facilities ${ }^{10}{ }_{-}{ }^{11}{ }_{-}{ }^{12}$ and types of subjects. This view shows that learning cannot be done on the basis of the wishes of the teachers, but must be preceded by a mature and good plan.

Apart from the planning aspect, learning management includes the learning implementation aspect. Regarding learning implementation, the teacher as a

8 Golchin Shafieian, "Defining Talent Management Components," International Science Publication and Consulting Service 2014 (2014): 1-7, https://doi.org/10.5899/2014/acte-00182.

9 Catherine Clarck and Brue M. Shore, Educating Students with High Ability (France: UNESCO Publishing, 1998).

10 Simin Ghavifekr and Wan Athirah Wan Rosdy, "Teaching and Learning with Technology: Effectiveness of ICT Integration in Schools," International Journal of Research in Education and Science (IJRES) 1, no. 2 (2015): 175-91.

${ }_{11}$ Muhammad Yusuf, Mahyudin Ritonga, and Mursal, "Implementasi Karakter Disiplin Dalam Kurikulum 2013 Pada Bidang Studi PAI Di SMA Islam Terpadu Darul Hikmah,” Jurnal $\begin{array}{lllll}\text { Tarbiyatuna } & 11, & \text { no. } & \text { 49-60, }\end{array}$ https://doi.org/https://doi.org/10.31603/tarbiyatuna.v11i1.3437 Article.

12 Rosniati Hakim et al., "Institute Quality Improvement Through Management Training of Accreditation Preparation in TK Aisyiyah Bustanul Athfal Padang," in Advances in Social Science, Education and Humanities Research, Volume 449 Proceedings of the International Conference of Early Childhood Education (ICECE 2019), vol. 44 (Padang: ATLANTIS PRESS Advances in Social Science, Education and Humanities Research (ASSEHR), 2020), 55-65, https://doi.org/https://doi.org/10.2991/assehr.k.200715.012. 
manager must be able to manage learning from beginning to end ${ }^{13}$. According to Sudjana, learning implementation has two stages, namely pre-instructional and instructional ${ }^{14}$. In the instructional stage, the teacher provides learning material to students with indicators: a) the teacher explains the learning objectives that must be obtained by students, b) the teacher describes the learning material, c) the teacher discusses the material being taught, d) the teacher provides examples of the material learning, e) the use of media, $f$ ) and the use of learning methods.

Evaluation in learning management is a comprehensive activity that cannot be separated from all series of learning to measure the level of achievement in learning ${ }^{15}{ }^{16}$ the measured achievement is inseparable from predetermined goals, therefore, evaluation in learning must be based on the relationship between the learning material and evaluation instruments. Through evaluation, the teacher can find out the success obtained by students as well as the level of success in educating, because evaluation does not only function to assess students but also to evaluate the teacher himself.

By knowing these two aspects, a teacher will be able to make updates to learning management at the next meeting, because the teacher already knows the aspects that hinder the maximum learning objectives, in this case, an evaluator or teacher can innovate from the aspect of the plan or implementation aspect if the teacher finds weaknesses in both aspects.

\section{Method}

This study used a comparative qualitative approach because the data were in the form of words and sentences obtained from predetermined sources. The study was conducted at SD Negeri 02 and 13 Petok Pasaman, because based on preliminary information, Islamic religious education learning management at the two institutions has not been maximally realized. Meanwhile, the data sources were principal, Islamic teachers, and several students and teachers who were selected by snowball sampling.

The data were collected by observation, interviews, and documentation. Observation was used to obtain data related to the reality and facts of Islamic religious education learning management in the two elementary schools. Meanwhile, the interview was used to obtain data directly from the principal and the Islamic teacher as well as people who know information about Islamic religious

13 Apri Wardana Ritonga et al., "E-Learning Process of Maharah Qira'ah in Higher Education during the Covid-19 Pandemic," International Journal of Higher Education 9, no. 6 (2020): 227-35, https://doi.org/10.5430/ijhe.v9n6p227.

14 Nana Sudjana, Dasar-Dasar Proses Belajar Mengajar (Bandung: Sinar Baru Algesindo, 2002).

15 Idrus L, "Evaluasi Dalam Proses Pembelajaran," AD A AR A: Jurnal Manajemen Pendidikan Islam 9, no. 2 (2019): 920-35.

16 Aprianto et al., “The Influence of Using Audio- Lingual Method on Students' Speaking Skill in Madrasah Diniyah Takmiliyah Awwaliyyah," Izdihar: Journal of Arabic Language Teaching, Linguistics, and Literature 3, no. 2 (2020): https://doi.org/https://doi.org/10.22219/jiz.v3i2.12514. 
education learning management at SD Negeri 02 and 13 Petok. The documentation was used to find out how an Islamic teacher carries out management based on document review.

Data were analyzed comparatively, where data obtained from SD Negeri 02 and SD Negeri 13 on learning management were compared to be analyzed according to theories related to learning management. The stages of this qualitative study were started from data collection, data classification, data reduction, data presentation, to conclusion.

\section{Result and Discussion}

This study has succeeded in finding Islamic religious education learning management at SD Negeri 02 and SD Negeri 13 Petok which includes learning plan, learning implementation, and learning evaluation which will be presented below:

\section{Islamic religious education learning plan at SD Negeri 02 Petok dan SD Negeri 13 Petok}

Learning plan by Islamic teacher at SD Negeri 02 dan 13 Petok can be described in Table 1 below:

Table 1. Islamic religious education learning plan at SD Negeri 02 dan 13 Petok

\begin{tabular}{|c|c|c|c|}
\hline \multicolumn{4}{|c|}{ Pasaman } \\
\hline No. & Indicator & SD Negeri 02 & SD Negeri 13 \\
\hline 1 & $\begin{array}{l}\text { Perform a needs } \\
\text { analysis }\end{array}$ & $\begin{array}{l}\text { Can be seen in the } \\
\text { learning plan document }\end{array}$ & $\begin{array}{l}\text { Can be seen in the } \\
\text { learning plan document }\end{array}$ \\
\hline 2 & $\begin{array}{l}\text { Analysis of student } \\
\text { character }\end{array}$ & $\begin{array}{l}\text { The teacher analyzes the } \\
\text { character of the students }\end{array}$ & $\begin{array}{l}\text { The teacher analyzes the } \\
\text { character of the students }\end{array}$ \\
\hline 3 & School environment & $\begin{array}{l}\text { There are adjustments to } \\
\text { the school environment }\end{array}$ & $\begin{array}{l}\text { There are no } \\
\text { adjustments to the } \\
\text { school environment }\end{array}$ \\
\hline 4 & $\begin{array}{l}\text { Facilities and } \\
\text { infrastructure }\end{array}$ & $\begin{array}{l}\text { There are supporting } \\
\text { facilities }\end{array}$ & $\begin{array}{l}\text { The facilities need to be } \\
\text { fixed }\end{array}$ \\
\hline 5 & $\begin{array}{l}\text { The content of } \\
\text { Islamic religious } \\
\text { education }\end{array}$ & $\begin{array}{l}\text { Plan according to the } \\
\text { content of Islamic } \\
\text { religious education }\end{array}$ & $\begin{array}{l}\text { Plan according to the } \\
\text { content of Islamic } \\
\text { religious education }\end{array}$ \\
\hline
\end{tabular}

In accordance with the data contained in Table 1, when the researcher conducted interviews with the Principal of SD Negeri 02 and 13 Petok, that before implementing the learning, the teacher had prepared a learning plan properly, this is in accordance with the results of interviews with Islamic teachers at SD Negeri 02 Petok. who stated that: "before I carry out learning in class, apart from preparing a learning plan and all kinds of things related to administrative fulfillment as a teacher, I first prepare myself with the maximum possible mastery of the material so that students can understand what I am conveying. In addition, I prepare the 
learning resources that can be used by students, prepare media and props that match the material, then prepare the materials needed to carry out the evaluation if possible".

This is in line with a statement by the Islamic teacher of SD Negeri 13 Petok who stated that "As a teacher, of course, I prepare myself before appearing in front of students. As for what I have prepared other than books as a learning resource is a learning plan. I admit that I am one of the teachers who is often late in submitting learning plans, but that doesn't mean I don't have an unwritten plan in my mind. I was late in submitting the learning plan because I was constrained by my inability to prepare it, and it was just a complement to the administration. Meanwhile, what is actually implemented is still in accordance with what is thought by considering the situation and condition of the students. "

Regarding the preparation of Islamic teachers before teaching, the Principal of SD Negeri 02 Petok stated that "basically, teachers must have prepared various things that are needed before carrying out learning, including Islamic teachers. So far I have seen and assessed that Islamic teachers have a complete learning plan in accordance with the applicable curriculum as a reference in teaching before learning begins. Furthermore, as the principal, I and all the teachers conduct workshops related to everything that needs to be prepared at the beginning of school. Thus teachers can meet various forms of teacher and school administration demands ".

Furthermore, the Principal of SD Negeri 13 Petok stated that "The learning plan is a written teacher plan that is not only a complement to the administration as a teacher for schools or supervisors. However, the learning plan is an important part that can be used as a foundation for teachers to carry out learning. Therefore, at the beginning of each semester, I as the principal make a policy to collect all forms of teacher learning tools including the learning plan. Although there are some teachers who are late in submitting, including Islamic teachers, it does not mean that they are intentional, but are constrained by several things such as age. However, by compiling and collecting learning plans, teachers can find out about the development of the material and the current curriculum.

During the study, researchers found that Islamic teachers at SD Negeri 02 Petok and Islamic teachers at SD Negeri 13 Petok have prepared a syllabus and learning plan according to the curriculum and learning material to be taught. However, teachers did not fully understand the basics of the learning plan. This is in line with a statement by Islamic teacher SD N 02 Petok that "Basically I know the foundation in developing the learning plan, but I do not fully understand and apply it in the learning plan".

It is different from the Islamic teacher SD Negeri 13 Petok who stated that "In theory, I do not know the basis for developing a learning plan, but indirectly all of these educational foundations have been implicitly considered in the learning plan". 
The learning plan is one part of the learning tool that must be designed and prepared by the teacher according to a certain format and reference and taking various things into account. This is in line with a statement by the Principal of SDN 02 Petok that "The preparation of learning plans by teachers follows the development of curriculum and government regulations in both format and content".

The Islamic teacher of SD N 02 Petok also stated that "The learning plan format that I designed is in accordance with The 2013 Revised Curriculum. In addition, the contents of the learning plan are also adjusted to the background abilities and needs of students. On the other hand, the Islamic teacher of SD 13 stated: "Directly, I did not type the learning plan. In terms of conceptual learning, of course, based on the latest curriculum. But sometimes because the implementation is not in accordance with the learning plan, the important thing is that I collect a learning plan even though I have to go through the help of others as mere administration. While the implementation, of course, I know what my students are like and how their abilities and learning methods are, and I think that understanding the material and understanding the characteristics and needs of students is more important than a good concept of learning plan but it is not implemented".

The principal of SDN 13 explained that "The learning plan arrangement must be adjusted to the applicable curriculum. The learning plan should have been thought out and conceptualized by a teacher because the teacher will also implement it. So the teacher must know and must design what kind of learning plan to be implemented according to the needs of students. Even though the concept is not purely a result of its own, it means that something is downloaded from certain websites, but herein lies the role of the teacher in thinking about and adapting it to the educational environment at hand. In addition, the activities of the Teacher Work Group (KKG) are also often carried out, so that's when every teacher should discuss all issues regarding education including the preparation and drafting of a learning plan."

During the study, researchers found that every Islamic teacher has a learning plan that is in accordance with the applicable curriculum. The researchers found the files of each teacher in the office. Sometimes the learning plan is brought by the Islamic teacher to the classroom while studying, but sometimes it is not. In relation to the learning materials designed, the Islamic Teacher of SDN 13 stated that "I compiled learning materials in addition to being based on the curriculum in the form of a syllabus, so the material design that I will convey takes into account the difficulty level of the material and the ability of students to understand the material".

As a form of plan or preparation for teachers to achieve learning objectives, in addition to learning plans and mastery of the material to be taught, Islamic teachers have also prepared the learning media, teaching aids and various learning 
resources, both learning resources provided by schools and those provided by the teacher to be reproduced by students according to student needs and abilities.

\section{Islamic religious education learning implementation at SD Negeri 02 Petok and SD Negeri 13 Petok}

Islamic religious education learning implementation at SD Negeri 02 and 13 Petok can be seen in Table 2 .

Table 2. Islamic religious education learning implementation at SD Negeri 02 and

13 Petok Pasaman

\begin{tabular}{|c|c|c|c|}
\hline No. & Indicator & SD Negeri 02 & SD Negeri 13 \\
\hline 1 & $\begin{array}{l}\text { Explanation of } \\
\text { learning objectives }\end{array}$ & $\begin{array}{l}\text { The teacher explains the } \\
\text { learning objectives }\end{array}$ & $\begin{array}{l}\text { The teacher explains the } \\
\text { topic }\end{array}$ \\
\hline 2 & $\begin{array}{l}\text { Explanation } \\
\text { material }\end{array}$ & $\begin{array}{l}\text { Islamic teacher describes } \\
\text { the learning material }\end{array}$ & $\begin{array}{l}\text { Islamic teacher explains } \\
\text { the material }\end{array}$ \\
\hline 3 & $\begin{array}{l}\text { Discussion } \\
\text { material }\end{array}$ & $\begin{array}{l}\text { The teacher and students } \\
\text { discuss the material }\end{array}$ & $\begin{array}{l}\text { Teachers do not fully } \\
\text { involve students }\end{array}$ \\
\hline 4 & Exemplification & $\begin{array}{l}\text { The teacher relates the } \\
\text { material to the context of } \\
\text { the students }\end{array}$ & $\begin{array}{l}\text { The teacher gives an } \\
\text { example conceptually }\end{array}$ \\
\hline 5 & Use of media & Variations in media use & $\begin{array}{l}\text { Only use conventional } \\
\text { media }\end{array}$ \\
\hline 6 & Use of method & $\begin{array}{l}\text { Use of the method } \\
\text { according to the material }\end{array}$ & $\begin{array}{l}\text { Teachers rely on the } \\
\text { lecture method }\end{array}$ \\
\hline
\end{tabular}

Table 2 shows the summary and conclusions from the results of observations, interviews, and documentation. From the results of the interview with the Islamic teacher, "The first thing I did to start learning apart from saying greetings and prayers was to first condition the students both the order and calmness of their studies and the completeness of the learning media. Next, I provide motivation in the form of advice or encouraging words in learning, then provide illustrations related to the material to be studied, then I convey the learning objectives. "

In this case, researchers found that before entering, students lined up first and greeted teachers, including the Islamic teacher. Researchers found that students were eager to participate in learning by listening to teacher stories related to the material. Researchers found that students enthusiastically shouted chants with movements that were able to relieve sleepiness and stress before studying.

The student of SD Negeri 02 stated that "I am very happy to learn Islamic religious education because before studying we like to yell". Another student added that "Islamic religious education learning is very fun because before the teacher explains the real material, I like hearing stories of teachers that make the whole class calm and quiet". Furthermore, Islamic teacher of SD Negeri 13 explained that "Greetings and prayers must be done to start the lesson, but I will add a little, 
where every time I have a meeting, I ask students to take turns at least one person to recite the memorized verse of the Qur'an. at least 2 verses. Then after that, I began to convey the learning objectives ".

The principal of SD Negeri 13 stated that "the way to start learning is a measure to raise the enthusiasm of students in the next stage. If the teacher can start learning with fun, then the students will be more enthusiastic ". Ongoing learning is not always conducive, sometimes it is constrained by the presence of negative actions from some students. In this case, the teacher of SD Negeri 02 stated that "if during the study there are students who look sleepy, then I try to provoke it again by saying yells, or sometimes giving questions and for students who can answer I will give rewards in the form of praise, applause or in the form of objects. Apart from that, sometimes I give games that can foster the enthusiasm of students".

The principal of SD Negeri 13 stated that "the use of media is one that can help students better understand the learning material. Delivery of learning materials can sometimes be constrained because there is no medium of delivery, so the material is difficult to convey. In addition, the conditions of students and classrooms can sometimes hamper the delivery of learning material. Thus the teacher must be able to find solutions so that material that is in accordance with the curriculum can be conveyed by the teacher to students. As is done by the Islamic teacher, that if the material is not finished and the exam schedule is getting closer, then the teacher will study extra in the afternoon.

This was confirmed by the Islamic teacher that "I often hold lessons in the afternoon to catch up with the material left behind, I also sometimes ask students to photocopy leftover material so that they don't take notes anymore". The teacher of SD Negeri 02 stated that "at the beginning of school, I had instructed the students so that all of them had a copy of the teaching materials according to the material I was going to teach. Thus, students only write other important things that may not be in the teaching material. Missing written material can be read by students. I also hold lessons in the afternoon both at school and at my house because I happen to be close to the school environment. Thus, in addition to discussing material more freely, my students and I also discussed questions more freely. Similar to starting learning, ending learning also has its own scenario. In this case, the principal of SD Negeri 02 also stated that the Islamic teacher closes learning in an orderly and calm manner. "

This is in line with a statement by the Islamic teacher of SD Negeri 02, "In terms of closing and ending lessons, I sometimes hold quizzes with prizes for students. Furthermore, I conveyed the learning objectives at the next meeting and gave assignments if necessary and asked students to prepare the things needed for the next meeting, either in the form of resource books, media, or teaching aids that could be obtained by students." The teacher of SDN 13, stated that "The learning plan should close or end structured learning, starting from concluding the material, giving assignments, delivering subsequent learning objectives to greetings and 
prayers. Basically, I try to follow things like this, but sometimes see the situation and condition of students after hearing the bell ring, then what happens is only greetings and prayers. On the other hand, sometimes because of the pressure to finish the material, the scenario in the final activity is also not fulfilled according to plan".

Islamic religious education learning evaluation at SD Negeri 02 and 13 Petok

Learning evaluation is not only carried out on students to know the learning outcomes. However, learning evaluations should be carried out on learning plans, learning implementation, and learning outcomes. However, based on the results of the study, researchers found Islamic teachers both at SD Negeri 02 Petok and SD Negeri 13 Petok only conducted an evaluation on learning outcomes.

Learning evaluation is an activity that must be performed by the teacher. By conducting evaluations, teachers can find out the success of student learning and the success of teacher teaching. In this case, the teacher of SD Negeri 02 Petok stated that "The form of evaluation to students is in the form of oral and written. An oral evaluation is in the form of memorization, while writing is in the form of multiple-choice and essays".

The teacher of SD Negeri 13 Petok stated that "I do the evaluation to students, sometimes orally and sometimes in writing according to the material and learning objectives. I do evaluations more often after finishing a subject matter. I provide important notes for students related to the material that I will evaluate ". The principal of SD N 02 Petok also stated that "The steps taken by the Islamic teacher in conducting evaluations are to provide guidelines for questions and discuss them with students then carry out the evaluation".

This was confirmed by the Islamic teacher that "before I give the evaluation questions, I first give the question guidelines if it is an evaluation in the form of a mid-semester evaluation and a final evaluation. But sometimes I also often provide evaluations at the end of the lesson to find out the understanding of students in mastering the material that has just been studied, either in the form of quizzes or exercises that I have previously prepared, both orally and in writing. "

This is in line with a statement of students that "we were given a copy of the question guidelines before the semester exams, but for daily exams, we just write down the question guidelines". Other students also stated that "we often do daily exams in the form of descriptions. However, there was also an oral examination, but before that the Islamic teacher asked us to memorize material, then we memorize it in front of the class ". Another student added that "The exams given by the teacher are in accordance with the material we have learned, not even much different from the guidelines we have discussed together before".

The Islamic teacher of SD Negeri 13 stated that "I always provide guidelines for questions before the end of semester evaluation only, while for daily evaluations I only determine what material will be tested and convey which points the students must memorize and understand". The principal of SD Negeri 13 
stated that before carrying out the final semester evaluation, usually all teachers, including Islamic teachers, distributed question guidelines to students. The questions that will appear are usually in accordance with the guidelines and material that has been studied".

The student confirmed the statement by the principal that "Before the exam, we got a question guide from the Islamic teacher for us to study at home. Sometimes some were discussed at school and sometimes some were not discussed. However, in my opinion, the problem is in accordance with the material we have studied and is not much different from the guidelines ". Regarding the Islamic religious education learning outcome, the principal of SD Negeri 02 Petok stated that: "I always ask every teacher to analyze the evaluation results, including the Islamic teacher. Apart from being a complement to administration, analysis of the results of learning evaluation is very important to determine the next step for the teacher in dealing with students. In this case, if it turns out that the Islamic religious education learning outcome was low, then I and the teacher concerned mutually evaluate themselves and coordinate for follow-up, both to carry out remedial for some students with below-average abilities. "

The Islamic teacher of SD Negeri 02 also stated that "After carrying out the learning evaluation, the next step is the learning outcome analysis. Thus, I can find out which students do not understand which material and which materials are less understood by students both individually and as a whole. Then I analyzed which material I had to reiterate to students and which students I had to give exams as a follow-up. ".

Based on the results of the analysis of the data above, it can be revealed that Islamic religious education learning management at SD Negeri 02 Petok has advantages in the aspect of learning implementation because teachers are able to use various learning media that lead to the use of information technology. This is in line with a study by Susanti et al that learning media has an influence on the level of learning quality ${ }^{17}{ }_{-}{ }^{18}{ }_{-}{ }^{19}{ }_{-}{ }^{20}$. The advantages seen in SD Negeri 02 can also be seen in

17 Elvia Susanti, Mahyudin Ritonga, and Bambang Bambang, "Pengaruh Penggunaan Media Powerpoint Terhadap Minat Belajar Bahasa Arab Siswa," Arabiyatuna: Jurnal Bahasa Arab 4, no. 1 (2020): 179-91, https:// doi.org/10.29240/jba.v4i1.1406.

18 Fitria Sartika and Mahyudin Ritonga, “Ta'tsir Isti'mal Al-Wasa'il Al-Sam'iyyah AlBashariyyah 'Ala Nataij Ta'lim Mufradat Al-Lughah Al-'Arabiyyah Lilfashl Al-Rabi' Fi Al-Madrasah Al-Ibtida'iyah Al-Islamiyyah Al-Hukumiyyah Parambahan Lambasi Payakumbuh,” Alfazuna 4, no. 2 (2020): 144-54, http://jurnalftk.uinsby.ac.id/index.php/alfazuna/article/view/592/261.

${ }^{19}$ Mahyudin Ritonga, Alwis Nazir, and Sri Wahyuni, Pengembangan Model Pembelajaran Bahasa Arab Berbasis Teknologi Informasi \& Komunikasi Dalam Dialektika Revolusi Industri 4.0 (Yogyakarta: Deepublish, 2020), https://books.google.co.id/books?hl=id\&lr=\&id=OEXYDwAAQBAJ\&oi=fnd\&pg=PP1\&ots=sb r9Fjm_t\&sig=gqKsqW7fcokp_ya5MQd1zMZfQGE\&redir_esc $=\mathrm{y} \# \mathrm{v}=$ onepage\&q\&f $=$ false.

${ }^{20}$ Mahyudin Ritonga, Alwis Nazir, and Sri Wahyuni, "Pembelajaran Bahasa Arab Berbasis Teknologi Informasi Dan Komunikasi," Arabiyat: Jurnal Pendidikan Babasa Arab Dan Kebahasaaraban 3, no. 1 (2016): 1-12, https://doi.org/http://dx.doi.org/10.15408/a.v3i1.2879. 
learning management in the implementation aspect, namely that Islamic teachers are able to use a variety of learning methods so that students are more enthusiastic about participating in learning.

In accordance with the learning orientation that must lead to learning outcomes $^{21}$, Islamic religious education learning management should be carried out thoroughly and with quality ${ }^{22}$, starting from learning plans, learning implementation, to learning evaluations, because it is in accordance with the study by Saggaf et al, learning management in the classroom affects the learning outcome 23. These results indicate that the pattern of Islamic religious education learning management at SD Negeri 02 and 13 Petok Pasaman requires innovation to realize good learning outcomes.

\section{Penutup}

Based on the study on Islamic education learning management at SD Negeri 02 and 13 Petok Pasaman, first, in learning plans, Islamic teachers carry out various preparations and designs before implementing learning, the preparation of learning plans was carried out through studies of various aspects related to learning. Second, the learning implementation by the teachers of SDN 02 was quite creative and innovative, in contrast to the Islamic religious education at SD Negeri 13 which still relies on conventional aspects of learning methods and media. Third, in terms of learning evaluation, the Islamic teacher of SD Negeri 02 Petok conducted a conceptual, structured, and systematic learning evaluation.

\section{References}

A.Aziz, Azmahani, Khairiyah M. Yusof, and Jamaludin M. Yatim. "Evaluation on the Effectiveness of Learning Outcomes from Students' Perspectives." Procedia-Social and Behavioral Science 56 (2012): 22-30.

Aprianto, Mahyudin Ritonga, Yoni Marlius, and Raihan Nusyur. "The Influence of Using Audio- Lingual Method on Students' Speaking Skill in Madrasah Diniyah Takmiliyah Awwaliyyah." Iqdihar: Journal of Arabic Language Teaching, Linguistics, and Literature 3, no. 2 (2020): 149-62. https://doi.org/https://doi.org/10.22219/jiz.v3i2.12514.

Clarck, Catherine, and Brue M. Shore. Educating Students with High Ability. France: UNESCO Publishing, 1998.

Darling-hammond, Linda, Lisa Flook, Channa Cook-harvey, Brigid Barron, and

${ }^{21}$ Roger Harris and Berwyn Clayton, "The Current Emphasis on Learning Outcomes," International Journal of Training Research 17, no. 2 (2019): 93-97, https://doi.org/10.1080/14480220.2019.1644777.

${ }^{22}$ Mahyudin Ritonga et al., "Reformulating the Arabic Language Teaching Materials within the Framework of Generating New Cadres of Tarjih and Tajdid Ulama," International Journal of Advanced Science and Technology 29, no. 7 (2020): 185-90.

${ }^{23}$ M Said Saggaf, Rudi Salam, and Rifka, "The Effect of Classroom Management on Student Learning Outcomes," in The 1 St International Conference on Education, Science, Art and Technology (the 1st ICESAT), 2017, 98-102. 
David Osher. "Implications for Educational Practice of the Science of Learning and Development." Applied Developmental Science 24, no. 2 (2020): 97-140. https://doi.org/10.1080/10888691.2018.1537791.

Ghavifekr, Simin, and Wan Athirah Wan Rosdy. "Teaching and Learning with Technology: Effectiveness of ICT Integration in Schools." International Journal of Research in Education and Science (IJRES) 1, no. 2 (2015): 175-91.

Hager, Paul, Alison Lee, and Ann Reich. Practice, Learning and Change: Practice-Theory Perspectives on Prodessional Learning. New York: Springer Dordrecht Heidelberg, 2012.

Hakim, Rosniati, Khadijah, Mahyudin Ritonga, Weti Susanti, and Rahmi. "Institute Quality Improvement Through Management Training of Accreditation Preparation in TK Aisyiyah Bustanul Athfal Padang." In Advances in Social Science, Education and Humanities Research, Volume 449 Proceedings of the International Conference of Early Childhood Education (ICECE 2019), 44:55-65. Padang: ATLANTIS PRESS Advances in Social Science, Education and Humanities Research (ASSEHR), 2020. https://doi.org/https://doi.org/10.2991/assehr.k.200715.012.

Harris, Roger, and Berwyn Clayton. "The Current Emphasis on Learning Outcomes." International Journal of Training Research 17, no. 2 (2019): 93-97. https://doi.org/10.1080/14480220.2019.1644777.

L, Idrus. "Evaluasi Dalam Proses Pembelajaran." ADAARA: Jurnal Manajemen Pendidikan Islam 9, no. 2 (2019): 920-35.

Maharani, Deviana Ika, M. Huda A.Y, and Imron Arifin. "Manajemen Pembelajaran Pondok Pesantren." JMSP Journal Manajemen Dan Supervisi Pendidikan 1, no. 1 (2016): 17-23.

Outhwaite, Laura A, Anthea Gulliford, and Nicola J Pitchford. "A New Methodological Approach for Evaluating the Impact of Educational Intervention Implementation on Learning Outcomes." International Journal of Research \& Method in Education 43, no. 3 (2020): 225-42. https://doi.org/10.1080/1743727X.2019.1657081.

Qasim, Muhammad, and Maskiah. "Perencanaan Pengajaran Dalam Kegiatan Pembelajaran." Jurnal Diskursus Islam 04, no. 03 (2016): 484-92.

Ritonga, Apri Wardana, Mahyudin Ritonga, Talqis Nurdianto, Martin Kustati, Rehani, Ahmad Lahmi, Yasmadi, and Pahri. "E-Learning Process of Maharah Qira'ah in Higher Education during the Covid-19 Pandemic." International Joumal of Higher Education 9, no. 6 (2020): 227-35. https://doi.org/10.5430/ijhe.v9n6p227.

Ritonga, Mahyudin. "Desain Bahan Ajar Bahasa Arab Sains Dengan Pendekatan Whole Language." EDUKASI: Jurnal Pendidikan Islam 5, no. 2 (2017): 001024. https://doi.org/https://doi.org/10.5281/edukasi.v5i2.287.

Ritonga, Mahyudin, Hafni Bustami, Riki Saputra, Rosniati Hakim, Mursal, Shofwan Karim Elhusen, and Yoni Marlius. "Reformulating the Arabic Language Teaching Materials within the Framework of Generating New Cadres of Jurnal WARAQAT • Volume V, No. 2, Juli-Desember $2020 \mid 58$ 
Tarjih and Tajdid Ulama." International Journal of Advanced Science and Technology 29, no. 7 (2020): 185-90.

Ritonga, Mahyudin, Alwis Nazir, and Sri Wahyuni. "Pembelajaran Bahasa Arab Berbasis Teknologi Informasi Dan Komunikasi." Arabiyat: Jurnal Pendidikan Bahasa Arab Dan Kebahasaaraban 3, no. 1 (2016): 1-12. https://doi.org/http://dx.doi.org/10.15408/a.v3i1.2879.

- Pengembangan Model Pembelajaran Bahasa Arab Berbasis Teknologi Informasi \& Komunikasi Dalam Dialektika Revolusi Industri 4.0. Yogyakarta: Deepublish, 2020.

https://books.google.co.id/books?hl=id\&lr=\&id=OEXYDwAAQBAJ\&oi $=$ fnd\&pg $=$ PP1\&ots $=$ sbr9Fjm_t\&sig $=$ gqKsqW7fcokp_ya5MQd1zMZfQ GE\&redir_esc $=\mathrm{y} \# \mathrm{v}=$ onepage\&q\&f$=$ false.

Saggaf, M Said, Rudi Salam, and Rifka. "The Effect of Classroom Management on Student Learning Outcomes." In The 1St International Conference on Education, Science, Art and Technology (the 1st ICESAT), 98-102, 2017.

Sartika, Fitria, and Mahyudin Ritonga. 'Ta'tsir Isti'mal Al-Wasa'il Al-Sam'iyyah AlBashariyyah 'Ala Nataij Ta'lim Mufradat Al-Lughah Al-'Arabiyyah Lilfashl Al-Rabi' Fi Al-Madrasah Al-Ibtida'iyah Al-Islamiyyah Al-Hukumiyyah Parambahan Lambasi Payakumbuh." Alfaruna 4, no. 2 (2020): 144-54. http://jurnalftk.uinsby.ac.id/index.php/alfazuna/article/view/592/261.

Shafieian, Golchin. "Defining Talent Management Components." International Science Publication and Consulting Service 2014 (2014): 1-7. https://doi.org/10.5899/2014/acte-00182.

Sudjana, Nana. Dasar-Dasar Proses Belajar Mengajar. Bandung: Sinar Baru Algesindo, 2002.

Susanti, Elvia, Mahyudin Ritonga, and Bambang Bambang. "Pengaruh Penggunaan Media Powerpoint Terhadap Minat Belajar Bahasa Arab Siswa." Arabiyatuna: Jurnal Bahasa Arab 4, no. 1 (2020): 179-91. https://doi.org/10.29240/jba.v4i1.1406.

Yusuf, Muhammad, Mahyudin Ritonga, and Mursal. "Implementasi Karakter Disiplin Dalam Kurikulum 2013 Pada Bidang Studi PAI Di SMA Islam Terpadu Darul Hikmah." Jurnal Tarbiyatuna 11, no. 1 (2020): 49-60. https://doi.org/https://doi.org/10.31603/tarbiyatuna.v11i1.3437 Article. 